\title{
Ebola: Lessons learned
}

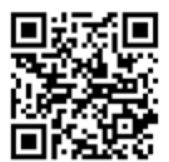

On Ebola we went from global indifference, to global fear, to global response and now to global fatigue. We must finish the job. (Joanne Liu, President, Médicins sans Frontières, July 2015 $5^{[1]}$ )

The international response to the Ebola outbreak in West Africa was slow and inadequate, destroying families, economies and the already fragile health systems of Guinea, Liberia and Sierra Leone. ${ }^{[2]}$ To date, there have been 27705 documented cases and 11269 reported deaths. ${ }^{[3]}$

Previous Ebola outbreaks occurred in isolated areas of Central Africa, affected at most a few hundred people, and were rapidly contained. ${ }^{[4]}$ There were more cases and more deaths with this West African outbreak than with all previous outbreaks added together. It is important that lessons are learned so that a humanitarian crisis on this scale never occurs again, whether due to Ebola or another infectious disease.

\section{Ebola is real}

'Ebola is real' appeared on posters everywhere in Monrovia. In Liberia they referred to cultural traditions, and the widespread belief that Ebola is caused by witchcraft. ${ }^{[5]}$ Treatment centres were regarded with suspicion; rumours abounded that patients were given tablets that caused death. Challenging misconceptions of disease causation is not a simple matter of 'health education'. Infection control measures such as mass quarantine and isolation were imposed to varying extents at different times during the outbreak. However reasonable these may have seemed in theory, in practice they tended to be seen as coercive social control, engendering further mistrust in healthcare providers and contributing to further transmission. ${ }^{[6]}$

'Ebola is real' is also a message the world should have recognised many months earlier. When Ebola appeared to affect only poor African countries, it was easily ignored. The World Health Organization declared a Global Health Emergency in August 2014. This was 5 months after Médicins sans Frontières had launched an emergency response, and there were then only 49 infections and 29 deaths. ${ }^{[7]}$

When Ebola appeared in the USA and Europe, it became all too real; fear and irrationality set in. Healthcare workers returning from working with Ebola were vilified, and accused of selfishly putting the lives of the entire population at risk. ${ }^{[8]}$ Finally governments mobilised, sending in healthcare workers, military personnel, with their logistics experience, and funding. However, in resource-rich countries, Ebola at home was more of a concern than the thousands who were dying in West Africa. ${ }^{[9]}$

\section{Optimising survival}

Until this outbreak, death seemed an almost inevitable consequence of infection with Ebola, with mortality around $90 \% \cdot{ }^{[3]}$ Overall, $60 \%$ of people have died in the current outbreak; surviving Ebola in Africa is no longer a rarity. Survival rates have been higher for the small number of people treated in resource-rich countries. Improving survival is therefore on the agenda. The need to understand Ebola's pathophysiology better in order to optimise goal-directed care is now clear. ${ }^{[10]}$

Supportive care alone is not enough. Specific treatments are also needed, but can only be properly tested in an outbreak setting. The ethical issues involved in conducting clinical trials in vulnerable patients at high risk of imminent death are challenging. ${ }^{[11]}$ Trial design has been much debated, from both ethical and scientific perspectives. ${ }^{[12-14]}$ Non-randomised trials of two antiviral drugs, favipiravir and brincidofovir, and of passive immunisation with convalescent plasma, began in late 2014/early 2015. ${ }^{[15]}$ However, by the time the trials were implemented, there had been a significant reduction in new cases, and consequent lack of recruitment. A further lesson learned is that clinical trials in an ever-changing outbreak need rapid and flexible implementation. ${ }^{[16]}$

\section{Ebola is not over yet}

Ebola is no longer headline news. At the height of the outbreak, there were hundreds of cases a week. Currently there are around 30, which before this outbreak would have been considered alarming rather than welcome news. ${ }^{[1]}$

This is not a time to forget about Ebola, or to concentrate only on doing everything better next time. Now is not the time for resourcerich nations to withdraw financial and human support. Deaths from non-Ebola causes are likely to significantly outnumber deaths from Ebola. $^{[17]}$ Closure of contaminated health facilities and deaths of already scarce health workers have had a severe impact on access to healthcare. Health workers, being 21 - 32 times more likely to become infected than the general adult population, suffered 879 confirmed infections and 510 deaths. ${ }^{[3,18]}$

Evidence is also increasing that for those who have survived, Ebola is not over yet. Survivors have faced stigma within their communities, and post-traumatic stress disorder is common. Physical sequelae are increasingly recognised. Common complaints of 'post-Ebola syndrome' include loss of vision, joint pains and general body pains. ${ }^{[19]}$ Viable virus seems capable of surviving in protected sites including aqueous humor, the testes and the fetoplacental unit. ${ }^{[20-22]}$ The implications for further transmission and the ongoing health needs of survivors are therefore of great concern.

\section{Ebola will not be eradicated by science alone}

Finally, this outbreak has clearly shown that infectious diseases cannot be separated from the context in which they occur. As has been all too apparent, historical, social, economic and political factors also determine the course of an epidemic, and the nature of the global response. ${ }^{[23]}$

\section{Rosie Burton}

Physician and Infectious Diseases Specialist, Khayelitsha District Hospital, Cape Town, South Africa, and Department of Medicine, Groote Schuur Hospital, Cape Town

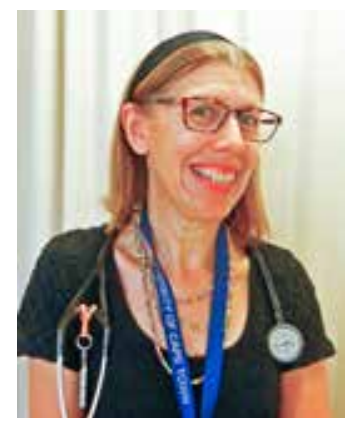

Médicins sans Frontières. Ebola in West Africa: 'We must finish the job' MSF July opetive update. 17 July 2015 . http://www.msf.org/article/ebola-west-africa-\%E2\%80\%9Cwe-must-finishjob\% $2 \% 80 \% 9 \mathrm{D}$ (accessed 23 July 2015).

2. Piot P, Muyembe JJ, Edmunds WJ. Ebola in West Africa: From disease outbreak to humanitarian crisis. Lancet Infect Dis 2014;14(11):1034-1035. [http://dx.doi.org/10.1016/S14733099(14)70956-9]

3. WHO Ebola Situation Report. 22 July 2105. http://apps.who.int/ebola/current-situation/ebolasituation-report-22-july-2015 (accessed 23 July 2015).

4. Kortepeter MG, Bausch DG, Bray M. Basic clinical and laboratory features of filoviral hemorrhagic fever. J Infect Dis 2011;204(Suppl 3):S810-S816. [http://dx.doi.org/10.1093/infdis/jir299]

Chandler C, Fairhead J, Kelly A, et al. Ebola: Limitations of correcting misinformation. Lance 2015;385(9975):1275-1277. [http://dx.doi.org/10.1016/S0140-6736(14)62382-5]

6. Eba PM. Ebola and human rights in West Africa. Lancet 2014;384(9960):2091-2093. [http://dx.doi. org/10.1016/S0140-6736(14)61412-4] 
7. Médicins sans Frontières. Guinea: Ebola epidemic declared, MSF launches emergency response. 22 March 2014. http://www.msf.org/article/guinea-ebola-epidemic-declared-msf-launches-emergencyresponse (accessed 23 July 2015)

8. Miles SH. Kaci Hickox: Public health and the politics of fear. Am J Bioeth 2015;15(4):17-19. [http:// dx.doi.org/10.1080/15265161.2015.1010994]

9. Editorial. The medium and the message of Ebola. Lancet 2014;384(9955):1641. [http://dx.doi org/10.1016/S0140-6736(14)62016-X]

10. Fletcher TE, Fowler RA, Beeching NJ. Understanding organ dysfunction in Ebola virus disease. Intensive Care Med 2014;40(12):1936-1939. [http://dx.doi.org/10.1007/s00134-014-3515-1]

1. Caplan AL. Morality in a time of Ebola. Lancet 2015;385(9971):e16-e17. [http://dx.doi.org/10.1016/ S0140-6736(14)61653-6

12. World Health Organization. Ethical considerations for use of unregistered interventions for Ebol virus disease. Report of an advisory panel to WHO. http://www.who.int/csr/resources/publications/ ebola/ethical-considerations/en/ (accessed 23 July 2015).

13. Cox E, Borio L, Temple R. Evaluating Ebola therapies - the case for RCTs. N Engl J Med 2014;371(25):2350-2351. [http://dx.doi.org/10.1056/NEJMp1414145]

14. Cooper BS, Boni MF, Pan-ngum W, et al. Evaluating clinical trial designs for investigational treatments of Ebola virus disease. PLoS Med 2015;12(4):e1001815. [http://dx.doi.org/10.1371/journal.pmed.1001815]

15. Gulland A. Clinical trials of Ebola therapies to begin in December. BMJ 2014;349:g6827. [http://dx.doi. org/10.1136/bmj.g6827]
16. Check Hayden E. Ebola R\&D woes spur action. Nature 2015;521(7553):405-406. [http://dx.doi. org/10.1038/521405a]

17. Helleringer S, Noymer A. Magnitude of Ebola relative to other causes of death in Liberia, Sierra Leone and Guinea. Lancet Glob Health 2015;3(5):e255-256. [http://dx.doi.org/10.1016/S2214-109X(15)70103-8]

18. World Health Organization. WHO Ebola report on health worker infections. Special Ebola situation report. 20 May 2015. http://www.who.int/csr/resources/publications/ebola/health-worker-infections/ en/ (accessed 25 July 2015)

19. Médicins sans Frontières. Ebola: Surviving survival - life after recovery. 13 April 2015. http://www.msf. org/article/ebola-surviving-survival-life-after-recovery (accessed 25 July 2015)

20. Varkey JB, Shantha JG, Crozier I, et al. Persistence of Ebola virus in ocular fluid during convalescence. N Engl J Med 2015;372(25):2423-2427. [http://dx.doi.org/ 10.1056/NEJMoa1500306]

21. Fecht S. Why testicles are the perfect hiding spot for Ebola. 5 May 2015. http://newsinformer.info/us-healthnews/why-testicles-are-the-perfect-hiding-spot-for-ebola-popular-science/ (accessed 25 July 2015)

22. Black, BO. Obstetrics in the time of Ebola: Challenges and dilemmas in providing lifesaving care during a deadly epidemic. BJOG 2015;122(3):284-286. [http://dx.doi.org/10.1111/1471-0528.13232]

23. Castillo-Chavez $C$ Curtiss $R$, Daszak $P$ et al. Beyond Ebola: Lessons to mitigate future pandemics. Lancet Glob Health 2015;3(7):e354-e355. [http://dx.doi.org/10.1016/\$2214-109X(15)00068-6]

S Afr Med J 2015;105(9):698-699. DOI:10.7196/SAMJnew.8492 